\title{
Lengthening of Short Vowels Incorrectly Under the Effect of Some Factors as a Problem Facing Students of the University of Anbar Concerned with Studying EFL
}

\author{
Muslih Shwaysh Ahmed ${ }^{1,2, *}$, Raafat N. Muneer Al-Heety ${ }^{1}$ \\ 1 College of Education for Humanities, University of Anbar, Iraq \\ 2 Department of English, Al-Maarif University College, Iraq \\ * ed.musleh.shweesh@uoanbar.edu.iq
}

\author{
KEYWORDS: $\quad$ English Vowels, Lengthening, Short Vowels, Errors, Vowel Letters.
}

\begin{abstract}
:
This study deals with a serious problem faced by Anbar University students studying English as a foreign language (EFL). These students tend to lengthen short vowels in English words incorrectly due to the effect of certain factors. The present study aims at investigating this problem because length is significant in English and any difference in the length of a vowel makes a different meaning. It is hypothesized that many students concerned with the study of EFL at Anbar University mispronounce English words by lengthening short vowels wrongly although they studied Phonetics and Phonology at the department of English, College of Education for Humanities due to certain factors. To achieve the aim of the study, a test consists of 50 English words that have simple vowels in different positions was prepared by the researchers. Twenty-five students were chosen randomly to participate in the test and they were asked to pronounce all the words which were selected purposely for the test. These students study English in the same grade and their native language is Arabic. The data were recorded in the first semester of the academic year 2019-2020 by using a cellphone. Then, the researchers analyzed them depending on Roach's (2010) model which is adopted because it follows the B.B.C. pronunciation, the variety taught in Iraqi universities. The findings of this study validate its hypothesis. The study has arrived at certain conclusions among them and the most significant ones are the influence of the students' native language upon the foreign language the students study because these two languages have two different vowel structures, besides the poor mastery of the English pronunciation. These causes and others play a great role in the occurrence of errors. Accordingly, the lengthening of short vowels is considered a problem that faces the students of the University of Anbar studying EFL which they need to overcome.
\end{abstract}

\section{1- Introduction}

English has a unique sound system. It has two categories: consonants and vowels. In this study, vowels are our concern. According to Crystal (2008:517), vowels are defined phonetically and phonologically. Phonetically, vowels are articulated without closure or obstacle in the vocal tract where the vowel sound is produced since the air escapes from the mouth freely. Phonologically, they are syllabic and they form the center (peak) of syllables. In English, the nucleus slot is formed only by a vowel (Wikipedia).

In English, there are simple vowels, diphthongs, and tripthongs. Each type has its own classification. The focus of this study is on the simple vowels. Collins and Mees (2003:13) define simple (pure or monothong) vowels as the sounds that have a steady-state, i. e. they remain constant and do not glide to another vowel as it is with diphthongs. A vowel consists of one single sound and it is represented by 
one symbol. English has 12 pure vowels. They are classified according to the quality and the quantity of the vowel. This study is mainly concerned with quantity as it refers to the length of the vowel. Therefore, vowels are classified here as short and long (Ogden, 2009:66).

This study aims mainly at studying the incorrect vowel lengthening of English short vowels due to certain factors which cause a problem to Anbar University students studying EFL. It is hypothesized that not all vowels are shortened. Students' lengthening is not completely random. Certain phonological environments make students lengthen short vowels.

\section{2- Problems in Pronunciation}

The first problem the learners face is that English has a system that is different from the native language. As mentioned above, English is a unique language and has a unique sound system. English words, as O'Connor (1980:1) states, are written in a way that is different from the way they are pronounced. Learners are to differentiate between letters and sounds. Letters are written and sounds are spoken. They are not to be mixed up. For instance, the words be /bi:/, see /si:/, and sea /si:/ contain the same vowel /i:/ although they are written differently. Some words have the same vowel letters but they are pronounced differently as in the words book /buk/, and boot/bu:t/ which have the same letters 'oo'. However, Arabic is different from English since it is pronounced as it is written.

These two different systems present a real problem to Iraqi learners of English as a foreign language. Arabic mostly interferes with English. So, we find students of English lengthen short vowels because they are still thinking of Arabic after spending many years in using it. Learning another language needs to avoid thinking of the native language as far as possible and this is somehow not easy because it has become deep-rooted. But, for children, the matter is certainly easier (ibid: 2-3).

Another problem is that English has a larger number of vowels than Arabic. This means that there are vowels in English that Arabic does not have. In English, there are 12 long and short vowels, while in Arabic according to the "softarabic" website, there are only three short vowels and three long ones. These vowels are literally called "movements". The long vowels are written as letters while short vowels are written as diacritic symbols. According to Clark and Yallop (1995:29), Classical Arabic has a three-vowel system where Arabic has three distinctive vowels, which are /i, a, and u/.

Although there are more differences between the two languages but the above problems are the most effective ones that affect the students' pronunciation of English vowels.

\section{3- Short and Long English Vowels}

According to Crystal (2008:273), vowel length (vowel quantity) is: a term used in phonetics to refer to the physical duration of a sound or utterance, and in phonology to refer to the relative durations of sounds and syllables when these are linguistically contrastive; also referred to as quantity. Sometimes the term is restricted to phonological contexts, the phonetic dimension being referred to as 'duration'. Phonologically long and short values are conventionally recognized, for both vowels and consonants. Languages often have one degree of phonological length, and may have more than one.

Quantity is one of the factors that differentiate between vowels of English. It refers to the length of vowels. Since this research is mainly about students' lengthening of English vowels, it is important to give a brief overview of long and short English vowels. Let's consider the following examples:

bid /bid/ and bead /bi:d/ /i-i:/

good /gud/ and food /fu:d/ /u-u:/

cad /kad/and card /ka:d/ /a-a:/ 
$\operatorname{cod} / \mathrm{kod} /$ and cord /ko:d/ /o-o:/

(for) ward /fo:wəd/ and word /wə:d//ə-ə:/ (Cruttenden, 2001:95)

As shown above, both short and long vowels are simple because they do not glide to another sound. Although diphthongs are sometimes considered long, they will not be dealt with in this research because it is not our concern. This research deals only with simple vowels.

\section{3-1 Short Vowels}

According to Davenport and Hannahs (2005:41), short vowels are 50-100 percent shorter than long vowels. The vowels in these words "sit" and "seat" are different. In addition to other characteristics of quality that each vowel has, the vowel /i/ in the first word is heard considerably shorter than the vowel of the second word "seat" /i:/. According to Roach (2010:14), short vowels of English are:

$1-$ / $1 /$ this sound is produced in the close front place, and just above the mid close area of the tongue. It is produced with the lips spread as in "sit"/sit/.

2- /e/ this sound is front and it is produced in the area between close-mid and open-mid. The lips here are slightly spread as in "set"/set/.

3- /a/ this is an open and front vowel. The lips here are spread as in "sat"/sat/.

4- $/ \Lambda /$ this is a central and more open vowel. It is produced with neutral lips as in "sun" $/ \mathrm{s} \Lambda \mathrm{n} /$.

5- /o/ this is a back vowel produced between the open and open-mid area of the tongue. It is a rounded vowel as in "socks"/soks/.

6- /u/ it is a more open and more central vowel produced with rounded lips "soot"/sut/.

7- /ə/ this is a central vowel produced with neutral lips as in "sector"/sektə/.

\section{3-2 Long Vowels}

Sloat et al (1978:19) believe that long vowels are the longer forms of some short vowels. Long vowels are transcribed with a colon [:]. Thus, the long vowel /i:/ is the longer form of /i/. According to Roach (2010:16-17), long vowels are five sounds that are longer than short vowels in similar phonological environments. This is because vowel sounds are different in length depending on the phonological environments they are in (like stress or the following vowel). The long vowels are not only different in length from the short vowels, but also in quality. These long vowels are described as follows:

1- /i:/ this vowel is more close and more front than the vowel /i/. The lips here are spread. Ex. (beat /bi:t/, mean /mi:n/ and peace /pi:s/).

2- /3:/ This vowel is mid-central and the lips here are neutral. This occurs in the words like (bird /b3:d/, fern /f3:n/ and purse /p3:s/).

3- /a:/ This is an open and back vowel. This vowel is produced with a neutral lips positon. (card /ka:d/, half /ha:f/ and pass /pa:s/).

4- / $\mathrm{J}: /$ This vowel is back and produced with strongly rounded lips. (board /bo:d/, torn /to:n/ and horse /ho:s/). 
5- /u:/ It is not fully back and close. The lips here rounded. (food /fu:d/, soon /su:n/ and loose /lu:s/). (ibid:17)

\section{4- Error Analysis}

According to the University of Minnesota's website, this term refers to a method adopted to identify the errors done by learners of a certain language and to decide whether they are systematic errors. Moreover, this method tries to explain and identify the reasons behind their occurrences. Such errors are so noticeable by the ears of native speakers of the target language although learners may not notice them. It is to be mentioned that even native speakers may commit errors, but these errors are unsystematic like slips of the tongue errors, while learners of the second language produce errors that native speakers may never make. Only errors that violate the systematic patterns of pronunciation are considered errors. These errors show something about the interlanguage of the learner and his/her underlying mastery of the rules of the language learned.

As cited by Al-khresheh (2016), Ellis (1994) believes that this method has four steps: data collection, error identification, error description, and explanation of errors. They are to be done in order which means that there's no explanation without identification or description. According to Keller (2010), data collection has three types of samples: massive (large number participants), specific (specific number of participants), and incidental sample (one participant). This current research studies a specific sample of 25 students. The next step is identification. After the sample is collected, the researcher is to identify the errors. We need to know here what is meant by errors and how to identify them. Alkhresheh (2016:52) declares that any linguistic form that a native would not produce is considered an error. So, any deviation from the proper pronunciation is considered an error except for the mistakes like slips of the tongue. Then comes the third step: error description. Describing errors helps categorize and classify the types of errors and make them easier to be explained. Errors include four types: omission, addition, selection, and disordering of elements. The fourth and the most important step is explanation. In this step, researchers explain why and how learners commit errors. Explaining the nature of errors helps put the needed remedies to help learners overcome the errors. The researcher is to identify the sources of errors committed to explain why they are produced.

According to Al-khresheh (ibid:54), two terms classify the source of error: interlingual errors (occur because of the native language effect) and intralingual errors (caused by the effect of the target language itself). Some learners transfer rules from their native language, which are not found in the target one, and apply them while performing the target one causing errors. These are called interlingual errors. For instance, Arabic has what is so-called "almad" (lengthening of vowels) in certain phonological environments. When Arabic learners of English face such environments, they tend to apply lengthening which causes errors in pronunciation. Errors are caused because of the effect of overgeneralizing certain rules and strategies of the target language, or because of incomplete mastery of a certain process or rule of the target language. For instance, learners would pronounce these two words (food and foot) in the same way just because the vowel letters look similar. Here, they overgeneralize the pronunciation of /u:/ in food over the pronunciation of the word foot $/ \mathrm{u} /$

\section{5- Methodology}

The sample of this study includes 25 third-stage students of English. Their native language is Arabic. Gender distinction in this study is not crucial. Moreover, all students of this sample have passed the first and the second years without failure. This is to make the sample students equal in taking the number of courses of phonetics and phonology. The population of the sample is 145 students where they are all third-grade students. To fulfill the aim of the study, a test consisted of 50 words was prepared by the researchers for the sample students. These words were familiar to the students as they were taken from the textbooks about Phonetics and Phonology they have studied. These words were chosen carefully for the study where they had vowels in different phonological environments. The students were asked to pronounce the words and record their pronunciations using a cellphone. After 
collecting the data, the researchers transcribed the recorded words carefully and analyzed them depending on Roach's (2010) model.

\section{6- Data Collection and Analysis}

\section{6-1 Data Collection}

This research analyzes the data collected depending on a model. It also studies the number of the occurrence of the wrong pronunciation committed by the students. A sample of 25 third class students (males and females) was chosen to make the study natural. The third-grade students were chosen because they already studied phonetics and phonology for two semesters. Data were collected using a cellphone. Each student recorded him/herself pronouncing 50 words chosen carefully to identify the errors. Different vowel letters and phonological environments were chosen carefully to discover the letters or the environments that make learners lengthen the short vowels.

\section{6-2 Data Analysis}

After each student has recorded the pronunciation of the 50 words, it is time to analyze the pronunciation of each word. The pronunciation of the student will be compared to the correct pronunciation of the same word given in Roach (2010). The researchers transcribe students' pronunciation of the words and then analyze them depending on the correct pronunciation. Pronouncing the letter $r$ at the end of the word is not considered incorrect as both are correct and this is not the focus of the study. The word "even" can be pronounced with a syllabic/n/ or with a schwa.

Notice table (1) below. It includes the words and their correct transcriptions, besides the transcriptions of the incorrect pronunciation.

Table (1): selected test words

\begin{tabular}{|c|c|c|c|c|c|c|}
\hline No. & Words & $\begin{array}{l}\text { Correct } \\
\text { Pronunciation }\end{array}$ & $\begin{array}{l}\text { No. of } \\
\text { Inc. } \\
\text { Pron. }\end{array}$ & $\begin{array}{l}\text { Incorrect } \\
\text { Pronunciation } \\
1\end{array}$ & $\begin{array}{l}\text { Incorrect } \\
\text { Pronunciation } \\
2\end{array}$ & $\begin{array}{l}\text { Incorrect } \\
\text { Pronunciation } \\
3\end{array}$ \\
\hline 1 & Orange & orind3 & 25 & orənd3 23 & orand3 2 & \\
\hline 2 & Author & $\mathrm{O}: \theta \partial$ & 11 & әи $\theta ә 5$ & оðว 6 & \\
\hline 3 & Thanks & $\theta \mathrm{a} k \mathrm{ks}$ & 1 & $\theta ə h \mathrm{ks}$ & & \\
\hline 4 & Ooze & $\mathrm{u}: \mathrm{z}$ & 17 & o:z 14 & $\begin{array}{ll}\text { Ozi } 2 \\
\end{array}$ & \\
\hline 5 & Offer & ofə & 7 & วfว 5 & afə 1 & o:fə 1 \\
\hline 6 & Answer & a: nsə & 18 & ansə 14 & วnsə 4 & \\
\hline 7 & Leather & leðə & 18 & lеіðə 5 & li:ðə 12 & liðə 1 \\
\hline 8 & Shoe & fu: & 8 & 与əu 7 & Jju 1 & \\
\hline 9 & Wood & wud & 22 & wu:d 21 & wid 1 & \\
\hline 10 & Event & ivent & 7 & i:vent 6 & əvent 1 & \\
\hline 11 & Onion & Anjən & 25 & onjon 13 & onjən 12 & \\
\hline 12 & Oblige & oblaid3 & 25 & oblaid3 21 & oblid3 5 & oblig 4 \\
\hline
\end{tabular}




\begin{tabular}{|c|c|c|c|c|c|c|}
\hline 13 & Ate & eit & 5 & i:t 4 & a:t 1 & \\
\hline 14 & Food & fu:d & 0 & & & \\
\hline 15 & Heart & ha:t & 7 & hə:rt 5 & hi:rt 2 & \\
\hline 16 & Even & i: vn & 4 & iven 4 & & \\
\hline 17 & Tongue & $t \wedge \mathrm{b}$ & 13 & tob 4 & toho 2 & $\operatorname{tab} 7$ \\
\hline 18 & Law & lo: & 16 & lau 6 & ləu 9 & lu: 1 \\
\hline 19 & Polite & pəlait & 25 & polait 17 & pulait 8 & \\
\hline 20 & Babies & beibiz & 24 & beibi:z 24 & & \\
\hline 21 & Foot & fut & 23 & fu:t 23 & & \\
\hline 22 & Star & sta: & 0 & & & \\
\hline 23 & Adverb & advə:b & 14 & ədvə:b 14 & & \\
\hline 24 & Wool & wul & 25 & wu:1 25 & & \\
\hline 25 & Seat & si:t & 2 & sit & set & \\
\hline 26 & Chef & Sef & 5 & tef 2 & di:f 3 & \\
\hline 27 & Draw & dro: & 10 & $\begin{array}{ll}\text { drau } & 8\end{array}$ & drəu 2 & \\
\hline 28 & Olive & oliv & 5 & oli:v 5 & & \\
\hline 29 & womanhood & wumənhud & 23 & wumənhu:d 23 & & \\
\hline 30 & Have & hav & 0 & & & \\
\hline 31 & Bought & bo:t & 13 & bəut 8 & bu:t 2 & baut 3 \\
\hline 32 & Reaction & $\operatorname{riak} \int \mathrm{n}$ & 8 & riəkfn 5 & $\operatorname{rek} \int \mathrm{n} 3$ & \\
\hline 33 & Young & $\bar{j} \wedge \mathrm{b}$ & 6 & jonb 3 & jah 3 & \\
\hline 34 & Fast & fa:st & 0 & & & \\
\hline 35 & Virus & vaiərəs & 25 & vairos 15 & veros 2 & vairəs 8 \\
\hline 36 & Prophet & profit & 3 & prufit 1 & proft 1 & $\begin{array}{ll}\text { profit } 1\end{array}$ \\
\hline 37 & Purpose & pa:pas & 15 & pə:pos 11 & porpos 4 & \\
\hline 38 & Soon & su:n & 2 & sun & $\mathrm{s} \Lambda \mathrm{n}$ & \\
\hline 39 & Says & sez & 6 & seiz 5 & siz & \\
\hline 40 & Early & ə:li & 0 & & & \\
\hline 41 & Were & พə: & 0 & & & \\
\hline 42 & Cities & sitiz & 23 & siti:z 23 & & \\
\hline 43 & Colour & kılə & 4 & kola 4 & & \\
\hline 44 & Ant & ant & 4 & a:nt 1 & ont 3 & \\
\hline 45 & Millions & miljənz & 11 & $\begin{array}{ll}\text { miljonz } 11\end{array}$ & & \\
\hline 46 & Key & ki: & 5 & kei 5 & & \\
\hline 47 & O'clock & aklok & 25 & oklok 25 & & \\
\hline
\end{tabular}




\begin{tabular}{|l|l|l|l|l|l|l|}
\hline 48 & Football & futbo:1 & 6 & futbol & & \\
\hline 49 & Blood & blıd & 14 & blod 4 & blu:d 9 & blo:d 1 \\
\hline 50 & Journey & d3ə:ni & 5 & d3o:ni 5 & & \\
\hline
\end{tabular}

\section{6-2-1 Discussion}

The above table shows the correct pronunciation of the 50 words and the number of the incorrect pronunciation of each word pronounced by the students recorded. It also shows the incorrect pronunciation forms of these words. This is important to explain how and why the incorrect pronunciation occurs. Although all incorrect pronunciations will be analyzed, the focus of this explanation will be mainly on the incorrect pronunciation where there is short-vowel lengthening. It will be explained in detail. This is to show the vowel letters or the phonological environments that make students commit errors and lengthen the short vowels. This does not happen randomly which means that not all short vowels are lengthened. In this discussion, this aspect will be explained in detail. It is to be mentioned that each word was pronounced in isolation which means they were not taken from conversations and it is supposed that there was no tension. Therefore, the psychological factors had no influence and they will not be considered here.

The discussion will focus mainly on the lengthening of short vowels with some discussions about other errors that include no lengthening. This is to identify the phonological environments wherein the short vowels are incorrectly lengthened.

\section{6-2-1-1 Possible Phonological Environments for Lengthening}

Some words have similar vowel letters where all are pronounced incorrectly with lengthening the short vowels. These words are "wood, foot, wool, womanhood, and blood". As shown in the above table, most students pronounced these words incorrectly. They pronounced them with a long vowel /u:/ instead of /u/ except for the word blood where it was pronounced as /blo:d/ and /blu:d/. This shows that such an environment makes students lengthen short vowels. Such errors happen because the words have two vowel letters oo. That made students join them into one long vowel /u:/ or /o:/. This is actually not surprising as English, generally, is written and pronounced differently. This is called spelling pronunciation where students pronounce words as they are written under the influence of their native language.

Out of 25 students, 17 students pronounced the word "ooze" incorrectly. Fourteen of them pronounced it with a long vowel, /o:/. This word is different from the above words in that its correct pronunciation originally has a long vowel /u:/ instead of /o:/. This is to show the effect of the spelling pronunciation that leads to incorrect meanings.

Twelve out of 18 students who pronounced the word "leather" incorrectly, pronounced it with a long vowel /i:/. Here, the two vowel letters e and a make a possible environment for lengthening as many words have these two letters and they are pronounced with a long vowel. On the other hand, seven students pronounced the word "heart" incorrectly where they pronounced it with the long vowel /i:/ or /ə:/. Yet, it is different from the word "leather" as the word "heart" is originally pronounced with a long vowel, not a short one. This environment is tricky where two vowel letters are pronounced as one short vowel in the word "leather".

Another environment where short vowels are lengthened is found in pluralizing words that end with y and preceded with a consonant. Pluralizing such words needs changing the letter y into $\mathrm{i}$ and then adding the plural suffix es. In this study, the words "babies" and "cities" were pronounced incorrectly by more than 23 students. They pronounced them with a long vowel /i:/ instead of the correct short 
vowel /i/. Because these words have two vowel letters, the students joined them together into a long vowel /i:/. This is heard in almost all words that are pluralized in such a way.

As for the words "even" and "event", the first one begins with /i:/ and the second one begins with /i/. Because of the two words have somehow similar forms; some students mispronounced the word "event" using an analogy. They pronounced it as /i:vent/ instead of /ivent/. This shows that there is a tendency to lengthen vowels regardless their accurate pronunciation. As for the words "ant" and "ate", show a less possible environment of lengthening. Although some students pronounced them with a long vowel, they are few. Anyway, the letter 'a' at the beginning of words can lead to mispronunciation as long vowels using the analogy with some words start with a like "after, answer, ask, etc."

The words "chef" and "olive" show a different matter. Although they do not have only one single vowel letter in one phonological environment, they showed possible situation of lengthening vowels. Yet, the number of students who lengthened the vowel is few. It is to be noted that students mispronounced also the first consonant where they substituted the sound $/ \mathrm{J} /$ with $/ \mathrm{g} /$, but this is not the focus of this research. The study also shows that some students lengthened the vowels in "bought" and "journey". However, it is not considered a possible environment of vowel lengthening because their vowels are originally long and some students substituted them with other long vowels.

Another word wherein lengthening occurred was the word "offer". But, only one student did so which makes it incorrect to make it a possible environment of lengthening. Therefore, it cannot be generalized.

\section{6-2-1-2 Environments Where Lengthening Does not Occur}

All the students studied pronounced the word "orange" incorrectly. They replaced the short vowel /i/ with the short vowels /a/ and / / /. So, the source of these errors is the vowel letter a. The students studied pronounced it as /a/ and / / / and excluded /i/. They did not expect that this letter would be pronounced as /i/ because in most cases the letter a is pronounced as /a:/ /a/ and /ə/ but not /i/. But, all are short.

Seven students pronounced the words "author" incorrectly. Three students pronounced it with a diphthong /ou/. Although, some consider diphthongs as long vowels they are still not simple. This occurs because there are two vowel letters a and $u$ in the same phonological environment. Although it has two vowel letters, no student pronounced it with a long vowel. This shows that lengthening is not random.

Because of its popularity, the word "thanks" was pronounced correctly except for one case where it was pronounced with a schwa. Yet, it is still a short vowel.

Since this study focuses mainly on the environments where short vowels are mistakenly lengthened, other words like the above ones where lengthening does not occur will not be analyzed. They all showed that they are not possible environments for short vowel lengthening.

\section{7- Conclusions}

This research has arrived at the following conclusions:

1- Although there are different environments for short vowel lengthening, the possibility is different. Words that have oo or ea letters are likely to be lengthened.

2- Lengthening occurs because of the phonological environment. English is written in a way different from the way it is pronounced. So seeing the two vowel letters, the students may join them together and pronounce them as one long vowel. 
3- The analogy also plays a vivid role in lengthening where some students lengthened some vowels because the words seemed similar to other words like "even" and event". Moreover, some letters are pronounced long in certain words like "answer" /a:nsə/ and short some others like "ant" /ant/. Using the analogy, students tend to lengthen the letter 'a' when it occurs at the beginning of the word.

4- Lengthening occurs because students lack practicing of the correct pronunciation of words, or because they learned the incorrect pronunciation from others.

5- The study also concludes that the difference in the number of vowels in SE and SA presents a problem to EFL students. In SA, there are 6 long and short vowels while in English, there are 12 simple vowels (long and short).

6- Both languages have different vowel structures and patterns that cause another problem to Anbar University students of English whose native language is Arabic because they have deep-rooted habits concerning it. This reveals the influence of Arabic on studying English.

\section{Bibliography}

Al-khresheh, Mohammad Hamad (2016). “A Review Study of Error Analysis Theory”. International Journal of Humanities and Social Science Research. 2016, 2, 49-59 https://www.researchgate.net/publication/299456806_A_Review_Study_of_Error_Analysis_Theory Retrieved in 13-7-2020

Davenport, Mike, and S. J. Hannahs (2005). Introducing Phonetics and Phonology. 2nd ed. London: Hodder Arnold.

Clark, John and Colin Yallop (1995). An Introduction to Phonetics and Phonology. 2nd ed. Blackwell Publishers Ltd.

Collins, Beverley S. and Inger M. Mees (2003). Practical Phonetics and Phonology: A Resource Book for Students. New York: Routledge.

Cruttenden, Allan (2001). Gimson's Pronunciation of English. 6th ed. Edward Arnold Publishers Limited.

Crystal, David (2008). A Dictionary of Linguistics and Phonetics. 6th ed. Oxford: Blackwell Publishing.

Keller, Tom (2010). Error Analysis in SLA: An Investigation of Errors Made by Polish Learners of English. Munich: GRIN Velag www.grin.com/document/319481 Retrieved in 10-8-2020

O’Connor, J.D. (1980). Better English Pronunciation. 2nd Edition. Cambridge: Cambridge University Press.

Ogden, Richard (2006). An Introduction to English Phonetics. Edinburgh: Edinburgh University Press.

Roach, Peter (2010). English Phonetics and Phonology: A Practical Course.4th ed. Cambridge: Cambridge University Press.

Sloat, Clarence, Sharon Henderson, and James E. Hoard (1978). Introduction to Phonology. USA: Prentice-Hall. Internet Resources:

Overview of Error Analysis https://carla.umn.edu/learnerlanguage/error_analysis.html Retrieved in 13/8/2020

Vowel. https://en.wikipedia.org/wiki/Vowel Retrieved in 13/7/2020

https://softarabic.com/vowels-in-arabic-short-vowels-sukun-shadda-and-tanwin/ 5-7-2020 


\section{Appendix}

\section{The Test}

Dear students, below are fifty words needed for a study. We kindly ask you pronounce them without consulting any dictionary or any tool of pronunciation and record yourselves. Be informed that the pronunciation will be used for the research and NO NAME will be mentioned. Please, make your pronunciation LOUD and CLEAR! Regards!

The Researchers

1. Orange

2. Author

3. Thanks

4. Ooze

5. Offer

6. Answer

7. Leather

8. Shoe

9. Wood

10. Event

11. Onion

12. Oblige

13. Ate

14. Food

15. Heart

16. Even

17. Tongue
18. Law

19. Polite

20. Babies

21. Foot

22. Star

23. Adverb

24. Wool

25. Seat

26. Chef

27. Draw

28. Olive

29. Womanhood

30. Have

31. Bought

32. Reaction

33. Young

34. Fast
35. Virus

36. Prophet

37. Purpose

38. Soon

39. Says

40. Early

41. Were

42. Cities

43. Colour

44. Ant

45. Millions

46. Key

47. O'clock

48. Football

49. Blood

50. Journey 
إطالة حروف العلة القصيرة بشكل غير صحيح تحت تأثير بعض العوامل كمشكلة تواجه طلاب جامعة الأنبار المعنيين بدراسة اللغة الإنجليزية كلغة أجنبية

$$
\begin{aligned}
& \text { أ.د. مصلح شويش أحمد21،*، م.م. رافت نزار منير الهيتي } 1
\end{aligned}
$$

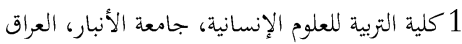

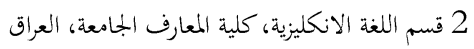

$$
\text { الكلمات المفتاحية | حروف العلة الإنجليزية، الاطالة، حروف العلة القصيرة، الأخطاء، حروف العلة. }
$$

\begin{tabular}{l|l} 
Crossref doi & https://doi.org/10.51345/.v33i1.470.g262
\end{tabular}

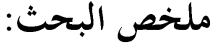

(EFL). تيميل هؤلاء

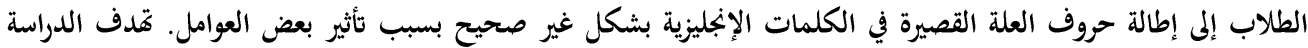

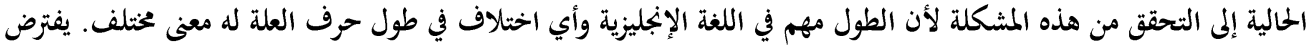

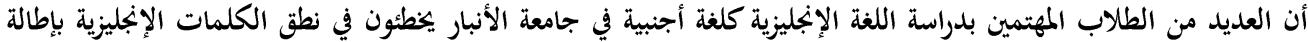

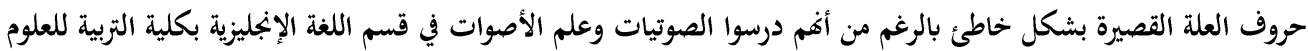

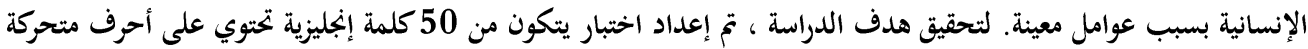

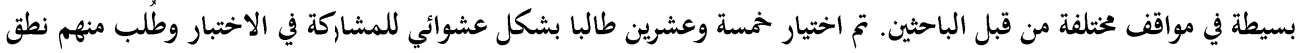

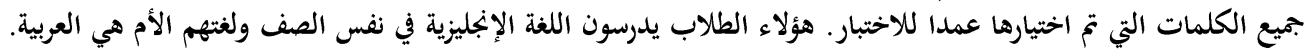

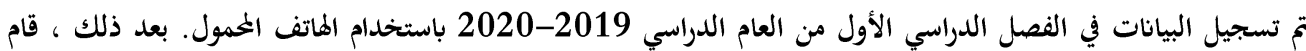

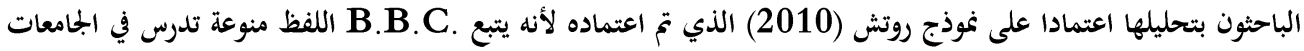

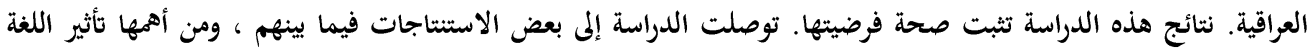

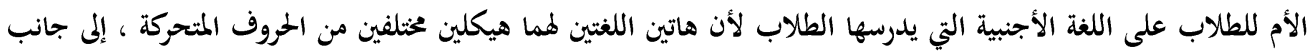

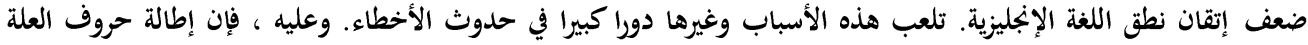

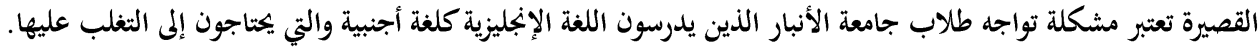

